\title{
FITUR LINGUISTIS TEKS BAHASA INDONESIA
}

\author{
Suhartono \\ Fakultas Bahasa dan Seni, Unesa \\ (hartonosuhartono@yahoo.co.id)
}

\begin{abstract}
Abstrak
Fitur linguistis berperan strategis dalam pendekatan pengajaran bahasa berbasis teks.Peran strategis tersebut terletak pada posisinya sebagai faktor distingtif antarjenis teks.Dengan memahami fitur linguistis, peserta didik mendapatkan kemudahan dalam membedakan antarjenis teks.Akan tetapi, fakta di lapangan menunjukkan fenomena yang berbeda karena fitur linguistis disamakan dengan aspek gramatika.Akibatnya, substansi kajiannya bukan fitur-fitur linguistis per jenis teks, melainkan aspek gramatika yang tidak dapat digunakan untuk membedakan antarjenis teks.Hal tersebut dalam perspektif akademis merupakan masalah besar yang perlu penanganan secepat-cepatnya agar pembelajaran dapat segera dikembalikan pada rel yang benar dan peserta didik tidak dirugikan.Terkait dengan hal tersebut, pada tulisan ini diuraikan fitur linguistis beberapa jenis teks sebagai sampel dan contoh-contohnya. Sampel yang dapat dikembangkan pada kesempatan yang berbeda dengan berdasar prinsip analogi dan komparasi tersebut diharapkan dapat menjadi inspirasi bagi penulis buku dan guru berbagai jenjang pendidikan dalam mengajarkan ragam teks bahasa Indonesia dengan pendekatan pengajaran bahasa berbasis teks.
\end{abstract}

Keyword:fitur, linguistis, teks, leksikal, gramatikal

\section{A. PENDAHULUAN}

Kalau perkembangan kurikulum mapel Bahasa Indonesia dicermati, satu hal yang segera tampak adalah inkonsistensi pengajaran aspek gramatika.Pada Kurikulum 1984 dan sebelumnya, sejalan dengan kekuatan pengaruh paham linguistik tradisional, aspek gramatika diajarkan secara eksplisit dan berperan dominan dalam kegiatan pengajaran (saat itu istilah "pengajaran" lebih sering digunakan daripada "pembelajaran”). Pada Kurikulum 1994, aspek gramatika juga diajarkan secara eksplisit, tetapi tidak dominan. Hal itu dipengaruhi dua hal.Pertama, sejalan dengan perkembangan pengaruh linguistik fungsional, desain pengajaran mulai dikonsentrasikan pada peminimalan kekuatan pengaruh linguistik tradisional.Kedua, sejalan dengan perkembangan pengaruh pendekatan komunikatif, desain pengajaran difokuskan pada penguasaan keterampilan berbahasa. Pada Kurikulum 2004, aspek gramatika masih diajarkan secara eksplisit, tetapi dengan sebab dua hal di depan makin tidak dominan. Hal itu 
tampak pada posisinya yang sekadar "lampiran" konten kurikulum.Kurikulum 2006 merupakan puncak dekonstruksi aspek gramatika. Pada kurikulum tersebut, aspek gramatika tidak dieksplisitkan dengan pertimbangan akan diajarkan oleh guru dengan cara diintegrasikan dengan konten keterampilan berbahasa. Fakta yang terjadi adalah mayoritas guru tidak mengajarkannya karena dengan sebab tidak dieksplisitkan dalam kurikum aspek gramatika tersebut dipandang tidak wajib diajarkan.Akibat hal tersebut adalah penguasaan siswa terhadap aspek gramatika rendah.Kondisi itu menyadarkan banyak pihak, khususnya pengembang kurikulum dan penulis buku teks bahwa bagaimana pun aspek gramatika perlu diajarkan oleh guru.Agar diajarkan, aspek gramatika dieksplisitkan seperti yang dapat diamati pada buku-buku teks Kurikulum 2013 saat ini.

Masalah-baru muncul karena aspek gramatika yang diajarkan bersifat gebyah uyah (sama rata) dan dalam hal tertentu tidak berbasis konsep. Sebagai contoh, pada materi teks eksposisi dalam buku Bahasa Indonesia Ekspresi Diri dan Akademik terbitan Kemendikbud diajarkan pronomina kita, kami, dan saya padahal pronomina tersebut bukan fitur linguistis teks eksposisi. Karena bukan fitur linguistisnya, pronomina tersebut tidak dapat digunakan untuk membedakan teks eksposisi dengan teks ragam lain. Dengan kata lain, materi aspek gramatika tersebut tidak memberikan kemudahan kepada siswa untuk membedakan teks eksposisi dengan teks eksplanasi atau anekdot, misalnya. Realitas tersebut dapat menjadi dasar rekomendasi bahwa sejalan dengan pendekatan pengajaran berbasis teks (text-based approach) yang digunakan dalam mapel Bahasa Indonesia pada Kurikulum 2013, aspek gramatika perlu dibedakan dengan fitur linguistis teks karena, sebagaimana dinyatakan Biber dan Conrad (2009:6), fitur linguistis mencakup tipikal leksikal dan karakteristik gramatikal. Dengan demikian, fitur linguistis merupakan tipikal leksikal dan karakteristik gramatikal yang menjadi fitur distingtif suatu teks dan keberadaannya dapat digunakan untuk membedakan teks tersebut dengan teks lain.

Untuk memberikan ruang pada kajianlain, kajian tentang teks dan fitur linguistisnya dalam tulisan ini dibatasi sebagai berikut. Pertama, semua kajian tentang teks dan fitur linguistisnya disikapi dari perspektif pendekatan pengajaran berbasis teks yang konsep-konsepnya dimungkinkan berbeda dengan perspektif 
lain. Kedua, sampel fitur linguistis dibatasi pada beberapa teks yang diajarkan di SMA/MA karena pada jenjang tersebut penanganan kegiatan pembelajaran tidak sekomprehensif jenjang di bawahnya.

\section{Konsep dan Ragam Teks}

Istilah "teks" digunakan dalam banyak perspektif. Dalam perspektif pendekatan pengajaran berbasis teks, sejalan dengan pemikiran Richards (tanpa tahun:32), teks ialah sekuensi bahasa terstruktur yang digunakan dalam konteks dan cara yang spesifik, misalnya teks percakapan santai dengan teman, percakapan telepon untuk memastikan janji, dan teks diskusi pribadi untuk meminta nasihat. Tiap sekuensi terdiri atas bagian awal, bagian tengah, dan bagian akhir sesuai dengan norma organisasi dan isi serta tata bahasa dan kosakata yang sesuai.

Teks terdiri atas beberapa jenis. Dalam Certificates in Spoken and Written English, sebagaimana yang dinyatakan Richards (tanpa tahun:33), teks terdiri atas teks percakapan singkat, tata bahasa (form), prosedur, informasi, cerita, dan persuasi yang subtipenya sebagai berikut.

\section{Nmr. Tipe Teks Subtipe Teks}

1 Percakapan Percakapan sederhana terkait dengan informasi, singkat barang, dan layanan

Percakapan kompleks atau problematis

Percakapan santai

2 Tata bahasaTeks tata bahasa sederhana

(form) Teks tata bahasa kompleks

3 Prosedur Instruksi

Prosedur

Protokol

4 Informasi Deskripsi

Eksplanasi

Laporan 


$\begin{array}{lll} & & \text { Direktif } \\ & & \text { Teks kombinasi antartipe teks } \\ & \text { Cerita } & \text { Pengalaman } \\ & & \text { Naratif } \\ & \text { Persuasi } & \text { Teks opini } \\ & & \text { Eksposisi } \\ & & \text { Diskusi }\end{array}$

Teks juga dapat diperinci dengan cara lain. Dalam dokumen Common Ground (1990:13 - 35) yang diberikan kepada Literacy \& Education Research Network, misalnya, disebutkan bahwa teks terdiri atas dua kategori, yaitu teks cerita (story genres) dan teks faktual (factual genres). Kedua kategori teks tersebut, seperti yang dapat diamati pada perincian berikut, terdiri atas beberapa subtipe.

\section{Tipe Teks}

\section{Teks Cerita}

Naratif

Berita dramatis (news story)

Eksemplum (exemplum)

Anekdot

Pengalaman

\section{Teks Faktual}

Prosedur

Eksplanasi

Laporan

Eksposisi

Diskusi

Dengan menggunakan perspektif lain, Knapp dan Watkins (2005:97-249) membagi teks ke dalam lima kategori, yakni teks pendeskripsian, pengeksplanasian, penginstruksian, pengargumentasian, dan penarasian. Sementara itu, kategori yang lebih spesifik dinyatakan oleh Derewianka (2003:137): deskripsi, laporan informasi, prosedur, pengalaman, eksplanasi, cerita, respons, dan eksposisi.

Bagaimana pengategorian teks di wilayah lain? Terkait dengan hal tersebut, Richards (tanpa tahun:35) menyatakan bahwa tipe teks dalam silabus di Singapura sebagai berikut. 


$\begin{array}{ll}\text { Tipe Teks } & \text { Contoh } \\ \text { Prosedur } & \text { Prosedur penyelesaian tugas } \\ \text { Eksplanasi } & \text { Penjelasan tentang bagaimana dan mengapa } \\ & \text { sesuatu terjadi } \\ \text { Eksposisi } & \text { Reviu, argumen, dan debat } \\ \text { Pengalaman } & \text { Artikel majalah } \\ \text { faktual } & \text { Anekdot, diari/entri jurnal, biografi, dan } \\ \text { Pengalaman } & \text { autobiografi } \\ \text { pribadi } & \text { Lembar fakta (fact sheets) } \\ \text { Laporan informasi } & \text { Cerita, fable } \\ \text { Naratif } & \text { Dialog, surat formal/informal, email, dan catatan } \\ \text { Percakapan } & \text { singkat }\end{array}$

Sebagian tipe teks di depan, sebagaimana yang dapat diamati pada Permendikbud Nmr. 67 Tahun 2013 tentang Kerangka Dasar dan Struktur Kurikulum Sekolah Dasar/Madrasah Ibtidaiyah, Permendikbud Nmr. 68 Tahun 2013 tentang Kerangka Dasar dan Struktur Kurikulum Sekolah Menengah Pertama/Madrasah Tsanawiyah, dan Permendikbud Nmr. 69 Tahun 2013 tentang Kerangka Dasar dan Struktur Kurikulum Sekolah Menengah Atas/Madrasah Aliyah, sama atau mirip dengan teks-teks yang digunakan di Indonesia. Pada jenjang SD, SMP, dan SMA, tipe teks yang digunakan di Indonesia sebagai berikut.

\section{Jenjang SD/MI}

\begin{tabular}{lll} 
Deskriptif & permintaan maaf laporan buku \\
petunjuk/arahan & laporan informatif hasilPenjelasan \\
& observasi \\
terima kasih & surat tanggapan pribadi paparan iklan \\
\multicolumn{2}{l}{ cerita diri/personal Dongeng } & pantun dan syair
\end{tabular}




$\begin{array}{lll}\text { diagram/tabel } & \begin{array}{l}\text { permainan/dolanan } \\ \text { daerah }\end{array} & \text { cerita narasi sejarah } \\ \text { laporan sederhana } & \text { Instruksi } & \\ \text { cerita } & \text { narasi Wawancara } & \text { penjelasan/eksplanasi } \\ \text { sederhana } & & \text { ilmiah } \\ \text { buku harian } & \text { cerita petualangan } & \text { pidato persuasive } \\ \text { lirik puisi } & \text { ulasan buku } & \text { cerita fiksi sejarah }\end{array}$

Jenjang SMP/MTs

$\begin{array}{lll}\text { hasil observasi } & \text { cerita moral/fabel } & \text { Eksemplum } \\ \text { tanggapan deskriptif } & \text { ulasan } & \text { tanggapan kritis } \\ \text { eksposisi } & \text { diskusi } & \text { Tantangan } \\ \text { eksplanasi } & \text { cerita prosedur } & \text { rekaman percobaan } \\ \text { cerita pendek } & \text { cerita biografi } & \end{array}$

Jenjang SMA/MA

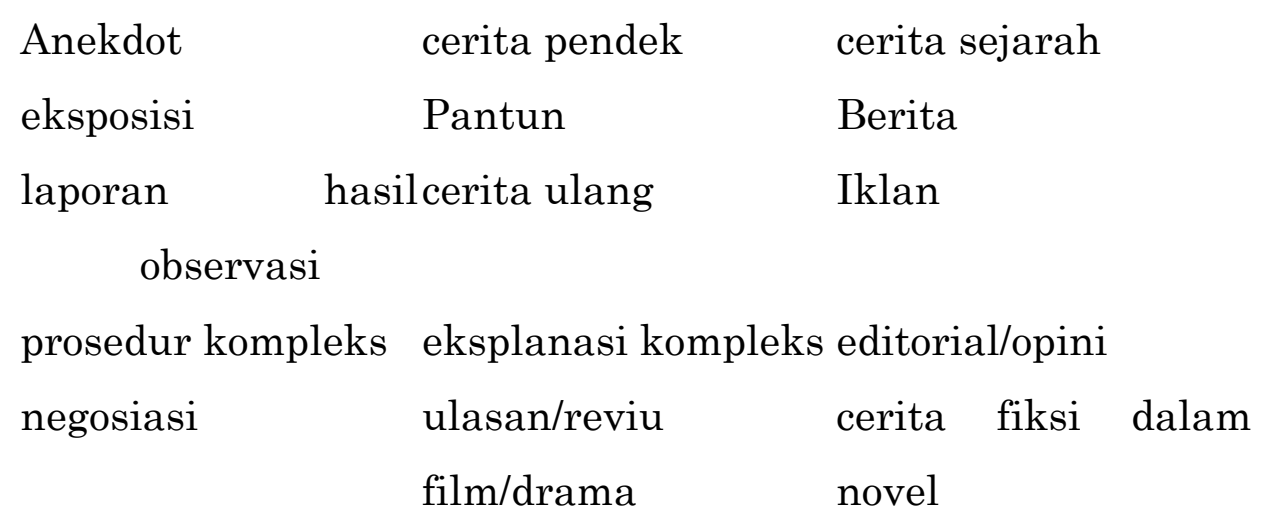

2. Komponen Teks

Dalam perspektif pengajaran berbasis teks, teks dikaji dengan berdasar komponen fungsi atau konsep, struktur skematis, dan fitur linguistis.Berikut contoh fungsi, struktur skematis, dan fitur linguistis teks anekdot yang berada pada domain genre cerita dan teks eksplanasi yang berada pada domain genre faktual. 
Teks anekdot

Teks eksplanasi

Fungsi/ Teks cerita tentang sesuatuTeks faktual tentang Konsep yang tidak diharapkan, tidakpenjelasan proses evolusi terduga, atau di luar kebiasaanfenomena natural atau yang sering berupa ragam lisansosiokultural untuk dalam percakapan santai danmemerhitungkan merupakan "sisipan" kejadianmengapa sesuatu yang tidak diharapkan—krisis—menjadi seperti itu. yang membuat pernyataan bernilai cerita dan menyebabkan pendengar ingin menyimak lebih lanjut.

Struktur

1. Krisis

. Pernyataan umum

skematis

2. Insiden (-insiden)

untuk pemosisian

3. evaluasi pembaca

$\therefore$ Pengurutan

mengapa/bagaimana sesuatu terjadi sampai dengan pernyataan final.

Fitur

1. Menggunakan kalimat. Fokus pada hal linguistis eksklamatif (misalnya coba generik, bukan tebak apa reaksinya! dan partisipan manusia bayangkan betapa hancur (non-human perasaan istrinya!), participants), misalnya pertanyaan retoris (misalnya hujan dan udara bagaimana istrinya harus setia. Menggunakan waktu kalau ia selalu begitu?), atau sekarang (simple pengintensif (intensifiers) present) (misalnya Mertuanya benar . Menggunakan 
benar tak habis pikir.) untuk konjungtor waktu atau menekankan signifikansi kausal, misalnya jika, kejadian. bila, sehingga,

2. Menggunakan konjungtor sebelum, pertama, dan waktu (misalnya kemudian) kemudian dan kontinuatif (misalnya.. Sering menggunakan baiklah) klausa material atau

3. Menggunakan proses klausa tindakan material atau tindakan (dalam (tindakan-tindakan waktu lampau atausekarang), wajar yang sesuai misalnya apa yang baru saja dengan kelaziman, terjadi! (waktu lampau)dan ini misalnya ...hujan sekadar langkah awal (waktu turun dan ...udara sekarang) bersih harus diproses

4. Menggunakan proses relasional (misalnya dia benarbenar pengkhianat.) dan mental (saya tidak mungkin dapat percaya) untuk evaluasi kejadian

(diadaptasi dari Common Ground, 1990)

\section{Pengajaran Teks}

Pengajaran teks dapat diamati dari dua perspektif, yakni konten dan pendekatan. Dari perspektif konten, yang diajarkan adalah komponen teks seperti yang diuraikan di depan. Dari perspektif pendekatan, teks diajarkan dengan pendekatan berbasis teks. Dalam pendekatan berbasis teks, teks diajarkan melalui tiga fase, yakni pemodelan, penyusunan teks melalui negosiasi kelompok, dan penyusunan teks secara mandiri (Common Ground, 1990:5) atau lima fase, yakni pembangunan konteks, pemodelan dan pendekonstruksian teks, penyusunan teks secara berkelompok, penyusunan teks secara mandiri, dan pengaitan teks dengan 
teks lain yang relevan (Feez dan Joyce dalam Richards, tanpa tahun:35-37). Fasefase tersebut dapat dikelompokkan ke dalam dua jenis, yakni fase yang wajib ada dan tidak wajib ada, seperti yang tampak pada uraian berikut.

\section{Fase Wajib}

\section{Fase Kegiatan Siswa}

Pembangunan 1. mempresentasikan konteks melalui gambar dan konteks sebagainya

2. menghadirkan tujuan sosial melalui diskusi, survei, dan sebagainya

3. melakukan aktivitas lintas budaya, misalnya pembandingan perbedaan penggunaan teks dalam dua budaya

4. membandingkan teks model dengan teks lain yang sama atau kontras

Pemodelan 1. mengeset konteks langsung untuk pembelajaran teks

2. menginvestigasi fokus fungsi sosial dan fungsi pembelajaran teks

3. mengeksplorasi relevansi bahasa teks pada konteks

Penyusunan 1. membuat keputusan tentang bagaimana mereka teks secara akan memeroleh, mengurutkan, dan berkelompok mengintegrasikan informasi yang diperolehnya ke dalam teks

2. mensketsa (scribe) dan mengatur (shape) hasil kerja kelompok ke dalam teks

Penyusunan 1. menulis draf tulisan secara mandiri teks secara 2. berkonsultasi dengan guru dan konferensi dengan mandiri pasangan tentang upaya-upaya penulisan secara mandiri

3. melakukan evaluasi kritis tentang upaya-upaya penulisan-termasuk penyuntingan dan publikasi 
4. melakukan eksploitasi kreatif teks dan kemungkinan-kemungkinannya

\section{Fase tidak Wajib}

Fase Kegiatan Siswa

Pendekonstru 1. mendekonstruksi teks baik pada teks utuh, klausa, ksian teks maupun level ekspresi

2. menginvestigasi pola-pola struktural dan ciri bahasa teks model

3. membandingkan model dengan contoh lain pada tipe teks yang sama

Pengaitan 1. membandingkan penggunaan teks pada bidang yang teks dengan berbeda

teks lain yang 2 . meneliti teks lain yang sebidang

relevan 3 . bermain peran tentang apa yang terjadi kalau teks yang sama digunakan oleh orang dengan peran dan hubungan yang berbeda

4. membandingkan mode lisan dan tulis pada teks sejenis

5. meneliti penggunaan ciri penting bahasa suatu tipe teks pada tipe teks lain

\section{Reviu Literatur}

Terdapat dua penelitian tentang fitur linguistis, yaitu penelitian Murniatie (2015) yang berjudul Pengembangan Bahan Ajar Menulis Teks Laporan Hasil ObservasiMelalui Web dengan Model Literasi Untuk Kelas X dan penelitian Fifiyanti (2015) yang berjudul Pengembangan Bahan Ajar Teks Negosiasi Menggunakan E-Learning Bermodel Pembelajaran Berbasis Masalah.Seperti yang terisyaratkan dalam judul, kedua penelitian tersebut merupakan penelitian dan pengembangan yang berfokus pada keseluruhan aspek teks. Dengan kata lain, fitur teks hanya menjadi bagiankecil. Seperti yang terdapat dalam buku-buku teks 
yang digunakan di sekolah, fitur linguistis teks laporan hasil observasi dalam penelitian Murniatie dan fitur linguistis teks negosiasi dalam penelitian Fifiyanti juga tidak distingtif karena disamakan dengan aspek gramatika. Sebagai contoh, dalam teks laporan hasil observasi yang dikembangkan Fifiyanti, fitur linguistis yang dikembangkan adalah konjungsi, paragraf kohesif, nomina, verba, adjektiva, dan kata baku.

\section{Metode Penelitian}

Penelitian ini merupakan penelitian deskriptif dengan sumber data buku teks berjudul Bahasa Indonesia: Ekspresi Diri dan Akademik terbitan Kemendikbud (2013). Data berupa fitur linguistis per jenis teks dikumpulkan dengan teknik dokumentasi. Data yang terkumpul kemudian dianalisis dengan model alir Miles dan Huberman (1984) yang terdiri atas reduksi data, penyajian data, dan verifikasi/penyimpulan.

\section{B. PEMBAHASAN}

1. Fitur Linguistik Teks

Dijelaskan di depan bahwa fitur linguistis mencakup tipikal leksikal dan karakteristik gramatikal yang menjadi fitur distingtif suatu teks dan keberadaannya dapat digunakan untuk membedakan teks tersebut dengan teks lain. Dengan berdasar hal tersebut, uraian tentang fitur linguistis teks prosedur (kompleks) yang diajarkan pada kelas X, teks cerpen yang diajarkan kelas XI, dan teks berita (dramatis) yang diajarkan pada kelas XII dikelompokkan ke dalam kategori tipikal leksikal dan karakteristik gramatikal.

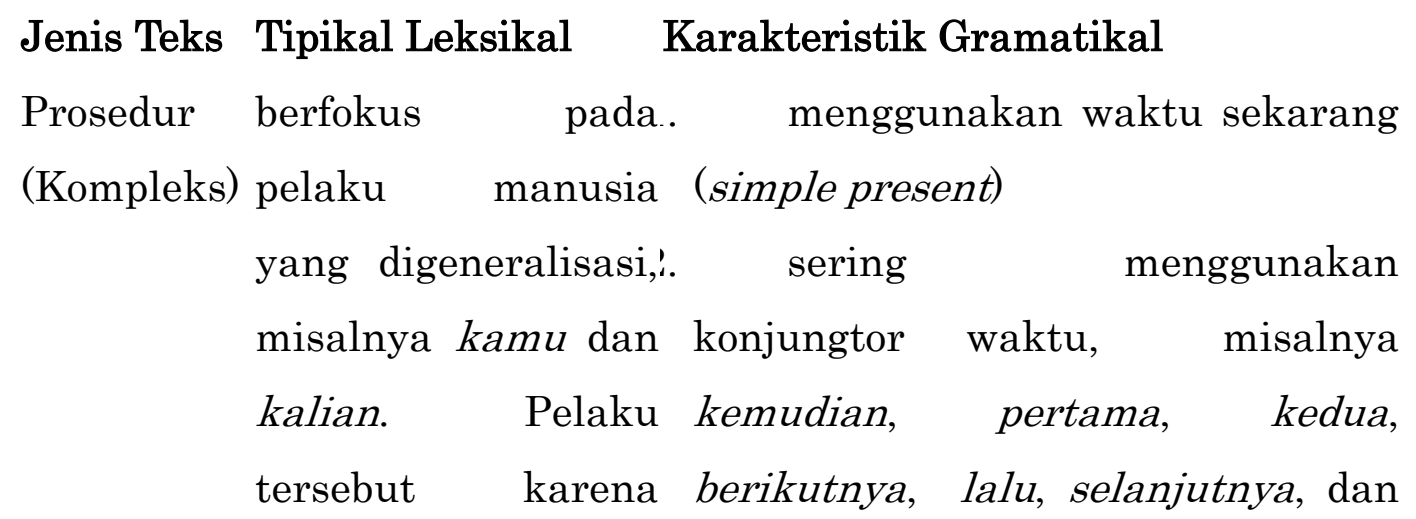


berstatus pronomina sekarang

II dimungkinkani. Sering menggunakan klausa didelisi karena material (tindakan) atau verba tipikal kalimat imperatif, misalnya ambil, berikan, dalam teks prosedur letakkan, daftar, tempatkan, uji, adalah imperatif. dan tutup

Cerpen berfokus pada. menggunakan waktu lampau, partisipan spesifik misalnya perempuan itu pernah (biasanya mengalami hal yangsama beberapa diindividualkan), tahun lalu misalnya $\quad \therefore$ menggunakan konjungtor perempuan itu dan waktu dan sirkumstansi waktu, anak pertamanya misalnya seminggu lalu dan sesekali

i. menggunakan proses material atau tindakan (terutama pada tahap "komplikasi" dan "resolusi"), misalnya dia hanya bisa mendongak manakala anaknya datang dan lelaki itu rupa-rupanya berupaya menjauh

$\therefore$ menggunakan proses relasional dan mental (pada tahap "orientasi" dan "evaluasi"), misalnya Dengan kejadian itu ia makin sedih dalam menjalani hari-harinya ke depan dan Orang-orang di sekelilingnya pun merasa dalam tekanan yang luar biasa

Berita berfokus pada. meringkas redaksi singkat Dramatis makna-makna (informasi telegrafis) tentang cerita 


\begin{tabular}{|c|c|}
\hline rkumstansial & ke dalam satu kalimat pokok berita \\
\hline $\begin{array}{ll}\text { (tampak } & \text { benar, } \\
\text { tetapi tidak } & \text { cukup }\end{array}$ & $\begin{array}{l}\text { (headline), misalnya Banjir } \\
\text { bandang sapu bersih dua desa. }\end{array}$ \\
\hline (terutama:. & menggunakan proses material \\
\hline tahap & atau tindakan untuk menyatakan \\
\hline "kejadian & kembali (re-tell) cerita, misalnya \\
\hline berita"), misalnya & mulai surut, meninggalkan, \\
\hline dalam kondisi yang & meratakan, dan menghancurkan \\
\hline tak bisa diharapkan. & menggunakan proses verbal \\
\hline lagi & saksi atau pemegang otoritas dalam \\
\hline & tahap "sumber informasi", misalnya \\
\hline & etempat menyatakan \\
\hline
\end{tabular}

\section{PENUTUP}

Fitur linguistis merupakan komponen teks yang pengajarannya perlu penataan ulang. Penataan tersebut diperlukan karena fitur linguistis sering disamakan dengan aspek gramatika yang tidak distingtif sehingga siswa kesulitan dalam mengidentifikasi teks dan membedakannya dengan teks lain. Untuk mengatasi hal tersebut, fitur linguistis perlu dipahami dan direalisasikan sesuai dengan konsepnya.

Sesuai dengan konsepnya, fitur linguistis suatu teks terdiri atas dua kategori, yakni tipikal leksikal dan karakteristik gramatikal.Keduanya membentuk kesatuan dan merupakan ciri distingtif antarteks. Penyikapan keduanya secara benar dalam materi pelajaran membantu siswa dalam mengidentifikasi teks dan membedakannya dengan teks lain.

\section{DAFTAR PUSTAKA}

Biber, Douglas dan Conrad, Susan. 2009. Register, Genre, and Style. Cambridge: Cambrdge University Press.

Common Ground. 1990. Book 1: An Introduction to Genre-Based Writing. Annandale: Common Ground.

Derewianka, Beverly. 2003. Trends and Issues in Genre-Based Approaches. RELC 
Journal. Vol. 34, hlm.133.

Fifiyanti, Galuh. 2015. Pengembangan Bahan Ajar Teks Negosiasi Menggunakan E-Learning Bermodel Pembelajaran Berbasis Masalah.Tesis tidak diterbitkan. Surabaya: PPs Unesa.

Knapp, Peler dan Watkins, Megan. 2005. Genre, Text, Grammar: Technologies for Teaching and Assessment Writing. New South Wales: New South Wales University.

Miles, M. B. \& Huberman, A. M.. 1984. Qualitative Data Analysis A Sourcebook of New Methods. London: Sage Publications.

Murniatie, Itznaniyah Umie. 2015.Pengembangan Bahan Ajar Menulis Teks Laporan Hasil ObservasiMelalui Web dengan Model Literasi Untuk Kelas $X$.Tesis tidak diterbitkan. Surabaya: PPs Unesa.

Permendikbud Nmr. 67 Tahun 2013 tentang Kerangka Dasar dan Struktur Kurikulum Sekolah Dasar/Madrasah Ibtidaiyah

Permendikbud Nmr. 69 Tahun 2013 tentang Kerangka Dasar dan Struktur Kurikulum Sekolah Menengah Pertama/Madrasah Tsanawiyah

Permendikbud Nmr. 69 Tahun 2013 tentang Kerangka Dasar dan Struktur Kurikulum Sekolah Menengah Atas/Madrasah Aliyah

Richards, Jack C. tanpa tahun.Communicative Language Teaching Today. Cambridge: Cambridge University Press. 